\title{
Bone Marrow Transplant Long-Term Survivors' Satisfaction with Quality of Life: Comparison with a Control Group
}

\author{
Maribel Pelaez Doro, José Zanis Neto, Denise Carvalho, Julita Maria Pelaez, \\ Vaneuza Funke, Ricardo Pasquini \\ International Society for Quality of Life Research (ISOQOL), Milwaukee, USA \\ Email: maripdoro@hotmail.com, jzanis@hc.ufpr.br, denisecarvalho@ufpr.br, julitamaria@bol.com.br, \\ vaneuzamf@uol.com.br, pasquini@hc.ufpr.br
}

Received 16 June 2014; revised 16 July 2014; accepted 16 August 2014

Copyright (C) 2014 by authors and Scientific Research Publishing Inc.

This work is licensed under the Creative Commons Attribution International License (CC BY). http://creativecommons.org/licenses/by/4.0/

(c) (i) Open Access

\begin{abstract}
Purpose: To evaluate the global quality of life (QoL) of survivors with 10-year or more post-transplant, and to identify risk factors that interfere with well-being. Methods: This is a prospective analytic transversal study with 214 survivors of Bone Marrow Transplant (BMT) and 264 healthy people identified among blood donors, treated as the control group, of both sexes, 18 years or older. The protocol includes a demographic-socioeconomic questionnaire, World Health Organization Quality of Life (WHOQOL) and the Karnofsky Performance Status Scale. Results: 53.7\% of the survivor group members are satisfied with their QoL. A similar result can be found in the control group (54.2\%). Chronological maturity, anxiety, sexual difficulty, and being a provider are factors that interfere negatively in the QoL of male survivors. In female survivors, the risk factors are anxiety, low educational level, not having a stable partner, being a provider, and not being Caucasian. Conclusions: Survivors are as satisfied with their QoL as the control group. QoL is understood as a perceptive process composed of objective (functional and relational capacity) and subjective phenomenon (perceptive composition).
\end{abstract}

\section{Keywords}

Quality of Life, Bone Marrow Transplantation, Long-Term Survivors, Control Group, Resilience

\section{Introduction}

Quality of Life (QoL) is a commonly used term, principally in questions regarding health, economics, and the

How to cite this paper: Doro, M.P., Neto, J.Z., Carvalho, D., Pelaez, J.M., Funke, V. and Pasquini, R. (2014) Bone Marrow Transplant Long-Term Survivors' Satisfaction with Quality of Life: Comparison with a Control Group. Open Journal of Medical Psychology, 3, 337-347. http://dx.doi.org/10.4236/ojmp.2014.35035 
environment. It's understood by the World Health Organization (WHO) as the individuals' perception of their zof bone marrow transplant patients has emerged as a critical area of investigation to enable a better understanding and quantification of post-transplant health.

BMT is a clinical procedure that involves lethal risk. However, it sometimes arises as the only possibility for survival. This intervention underscores human fragility in the presence of real threats to life. The patients encounter a multiplicity of side effects resulting from the illness and the treatment. These include anxiety, depression, stress, low self-esteem, and real or imaginary fears [3] [4].

In the literature, there is a growing interest in dimensioning $\mathrm{QoL}$ as tied to the health of survivors undergoing BMT [5] [6]. The post-treatment state and the illness-free survival time are considered indexes of effectiveness of treatment, and have become an integral part of the evaluation of medical results. In Brazil there has also been more attention paid to the nature of post-transplant survival associated with QoL [7].

The aim of this study is to evaluate the global quality of life (QoL) of long-term survivors who have undergone bone marrow transplants and to identify the level of satisfaction related to the domains that define the concept of QoL. The results are compared with a group of individuals from the general population.

The evaluation of QoL can qualify the process of clinical care, once it identifies the risk and protection factors that interact with the construction of the well-being of those who have undergone transplants [8]. Therefore, in this context, the objective of this study is justified.

\section{Methods}

A cross-sectional study was conducted with 478 participants, of which 214 belonged to the group of transplant survivors and 264 healthy individuals that were selected among the general population and constituted the control group. The survivors represented a sample of the patients undergoing BMT for hemopathies, through the Bone Marrow Transplant Service of the Hospital of the Clinics of the Federal University of Paraná-Brazil (BMTS-HC-UFPR). The individuals in the control group were recruited in the Curitiba Blood Bank. The project was approved by the Ethics in Investigation Committee of the HC-UFPR.

The inclusion criteria for the definition of the entire sample were agreement with and assignment of the free and informed consent forms. For the survivors, another criterion was added of ten or more year's post-transplant. And for the control group, the subject had to be a voluntary blood donor, free of chronic illness, and without the use of controlled medications. The study performed is a transversal of the QoL of survivors undergoing BMT, compared with a group of healthy people identified among blood donors.

\section{Instruments}

The study protocol consisted of three instruments: demographic and socioeconomic questionnaire, Quality of Life from World Health Organization (WHOQOL) [9] and Karnofsky Performance Status Scale (KPSS) [10].

The demographic and socioeconomic characterization of the sample was composed of the following variables: sex, age, marital status, children, educational level, race, and socioeconomic level, place of origin, profession, professional condition and religion.

The WHOQOL is an evaluation instrument of multidimensional QoL that is easy to apply and understand. It is composed of questions covering four domains: Physical, Psychological, Social Relationships, and Environmental. Other than the classification from 1 to 5 offered on the scale, a cut-off point was used, considering that the rankings between 5 and 4 would be categorized as satisfactory, and those of 3, 2, 1 as unsatisfactory. The values of QoL and of every domain were grouped into binary variables: satisfactory and unsatisfactory.

A review of records was also carried out to collect relevant information for the study, like time post-transplant, time between diagnosis and procedure, age of patient on the day of the transplant, diagnosis, type of transplant, source of stem cells, graft-versus-host disease (GVHD), and the KPSS level.

\section{Statistical Analysis}

A bivariate analysis was initially performed between the dependent and independent variable groups, using the variables with $p<0.20$ for the multivariate analysis. The Stata 8 model of logistical regression was used for this analysis. 
The multivariate analysis of QoL took in account the socio-demographic variables with a statistical significance of $p<0.05$ in the comparison of the two groups: without BMT and BMT.

\section{Results}

The demographic characteristics of the study population are organized in Table 1. In relation to the survivors, there was a predominance of men $(65 \%)$, an age range of above 36 years $(45.3 \%)$, married $(57.9 \%)$, no dependents $(64.5 \%)$, with a high level of education, above eight years of education (67.3\%). In relation to their socioeconomic level, the majority (64\%) are classified as low.

Table 1. Demographic characteristic for survivors and controls.

\begin{tabular}{|c|c|c|c|c|c|}
\hline & \multicolumn{2}{|c|}{ Survivors (214) } & \multicolumn{2}{|c|}{ Controls (264) } & \multirow[b]{2}{*}{$p$} \\
\hline Variables & $\mathrm{N}$ & $\%$ & $\mathrm{~N}$ & $\%$ & \\
\hline \multicolumn{6}{|l|}{ Gender } \\
\hline Female & 75 & 35.0 & 138 & 52.3 & $0.000^{*}$ \\
\hline Male & 139 & 65.0 & 126 & 47.7 & \\
\hline \multicolumn{6}{|l|}{ Age (years) } \\
\hline $18-25$ & 49 & 22.9 & 90 & 34.1 & $0.03^{*}$ \\
\hline $26-35$ & 68 & 31.8 & 69 & 26.1 & \\
\hline$>36$ & 97 & 45.3 & 105 & 39.8 & \\
\hline \multicolumn{6}{|l|}{ Marital Status } \\
\hline Married & 124 & 57.9 & 124 & 47.0 & \\
\hline Single & 90 & 42.1 & 140 & 53.0 & $0.02^{*}$ \\
\hline \multicolumn{6}{|l|}{ Children } \\
\hline Yes & 76 & 35.5 & 139 & 52.7 & \\
\hline No & 138 & 64.5 & 125 & 47.3 & $0.000^{*}$ \\
\hline \multicolumn{6}{|l|}{ Education } \\
\hline Up to 8 years & 70 & 32.7 & 44 & 16.7 & \\
\hline Above 8 years & 144 & 67.3 & 220 & 83.3 & $0.00^{*}$ \\
\hline \multicolumn{6}{|l|}{ Ethnic group } \\
\hline Caucasian & 187 & 87.4 & 218 & 82.6 & \\
\hline Others & 27 & 12.6 & 46 & 17.4 & 0.15 \\
\hline \multicolumn{6}{|l|}{ Economic Level } \\
\hline Médium/High & 77 & 36.0 & 126 & 47.7 & 0.01 \\
\hline Low & 137 & 64.0 & 138 & 52.3 & \\
\hline \multicolumn{6}{|l|}{ Origin } \\
\hline South & 171 & 79.9 & 259 & 98.1 & \\
\hline Others & 43 & 20.1 & 5 & 1.9 & $0.000^{*}$ \\
\hline \multicolumn{6}{|l|}{ Work type } \\
\hline $\begin{array}{l}\text { Professional } \\
\text { Intelectual }\end{array}$ & 125 & 58.4 & 150 & 56.8 & \\
\hline Labourer & 89 & 41.6 & 114 & 43.2 & 0.73 \\
\hline \multicolumn{6}{|c|}{ Occupational Status } \\
\hline Working & 178 & 83.2 & 150 & 87.9 & \\
\hline Not Working & 36 & 16.8 & 114 & 43.2 & $0.000^{*}$ \\
\hline \multicolumn{6}{|l|}{ Religion } \\
\hline Catholic & 174 & 81.3 & 157 & 59.5 & \\
\hline Others & 40 & 18.7 & 107 & 40.5 & $0.000^{*}$ \\
\hline
\end{tabular}

Note: * qui-square Person test. 
There was a predominance of white participants (87.4\%), from the south/southeast $(79.9 \%)$, employed $(83.2 \%)$, in relation to religion, the Catholic religion was dominant $(81.3 \%)$. In terms of the professional distribution, the majority were intellectuals (58.4\%).

In the control group, in relation to gender, subjects of the feminine sex were dominant (52.3\%), with an age range of above 36 years (39.8\%), single (53\%), with dependents (52.7\%). The percentage of individuals with a low family socioeconomic level $(52.3 \%)$ was similar to that of the survivor group.

A statistically significant difference was found in relation to place of origin $(p=0.000)$, with the predominant number of subjects coming from the south/southeast $(98.1 \%)$. This also happened in relation to educational level $(p=0.00)$; the majority had more than eight years of study (83.3\%). However, there was a statistically significant difference in the condition of employment $(p=0.000)$, in that the majority $(87.9 \%)$ was employed.

Table 2 shows the distribution according to time after BMT and from diagnosis to BMT, age, type of disease, type of donor and cell source. Among the survivors, 58.9\% underwent the transplant within the first year after being diagnosed, with an average time of between $5.2 \pm 3.3$ months. In relation to the post-BMT time, there was a prevalence of the survivor group that had the transplant 15 years ago $(78.5 \%)$. The percentage of survivors, who underwent the transplant with an age equal to or above 21 years, was $53.3 \%$. In relation to the diagnosis, non-malignant hemopathies were predominant, at $57.5 \%$. The majority of survivors $(98.5 \%)$ had a related donor and all the transplants had bone marrow as the cell source.

Table 3 illustrates the age distribution of the survivors at the time of transplant, as related to QoL.

The data obtained showed that there was no statistically significant correlation with the variable of age. The group composed of children/adolescents (100) and the group of adults (114) presented similar results, at 84\% and $79.8 \%$, respectively.

Table 2. Distribution according to time after BMT and from diagnosis to BMT, age, type of disease, type of donor and cell source.

$\begin{array}{lll}\text { Variables } & \text { N } & \%\end{array}$

Time after BMT (years)

$10-15$

$\geq 16$

Time from diagnosis to BMT

$0-12 \mathrm{~m}^{*}$

Age (years)

Type of disease

Related donor

Brother

Mother

Cell source

Marrow 
In relation to satisfaction or not with the global QoL, for the survivor and control groups, is organized in Table 4. It is observed that over the long-term post-BMT period, the base illness did not interfere with the perception of well-being of the survivors, once the majority (53.7\%) is satisfied with their current QoL. A similar result can be found within the control group (54.2\%).

Table 4 also presents the degree of satisfaction with their global QoL in terms of the domains. There is a linear correlation between the values and satisfaction: the higher the numerical value, the higher the degree of satisfaction. In the physical domain, $48.6 \%$ of the survivors presented answers corresponding to the highest level of satisfaction. Similar results were observed in the control group (43.5\%).

Table 3. Distribution of QoL satisfaction according to phase of life at BMT.

\begin{tabular}{cccc}
\hline & Child/Adolescent (84\%) & Adult & $p$ \\
\hline Satisfied & $84(84 \%)$ & $91(79.8 \%)$ & $n s$ \\
Unsatisfied & $16(16 \%)$ & $23(20.2 \%)$ & $n s$ \\
Total & 100 & 114 & \\
\hline
\end{tabular}

Note: Abbreviation $n s=$ not significant.

Table 4. Distribution according to QoL satisfaction at physical, psychological, social and environment domains.

\begin{tabular}{|c|c|c|c|c|}
\hline & \multicolumn{2}{|c|}{ Survivors (214) } & \multicolumn{2}{|c|}{ Controls (264) } \\
\hline & $\mathrm{N}$ & $\%$ & $\mathrm{~N}$ & $\%$ \\
\hline \multicolumn{5}{|l|}{ Global QoL } \\
\hline Satisfied & 115 & 53.7 & 143 & 54.2 \\
\hline Unsatisfied & 99 & 46.3 & 121 & 45.8 \\
\hline \multicolumn{5}{|c|}{ Physical domain } \\
\hline $0-15$ & & & 1 & 0.4 \\
\hline $16-25$ & 35 & 16.3 & 39 & 14.9 \\
\hline $26-30$ & 75 & 35.1 & 109 & 41.2 \\
\hline $31-35$ & 104 & 48.6 & 115 & 43.5 \\
\hline \multicolumn{5}{|c|}{ Psychological domain } \\
\hline $0-15$ & 3 & 1.5 & 5 & 1.9 \\
\hline $16-25$ & 126 & 58.9 & 180 & 68.1 \\
\hline $26-30$ & 85 & 39.6 & 79 & 30.0 \\
\hline \multicolumn{5}{|l|}{ Social domain } \\
\hline $0-5$ & 2 & 0.9 & 2 & 0.8 \\
\hline $6-10$ & 27 & 12.7 & 51 & 19.4 \\
\hline $11-15$ & 185 & 86.4 & 211 & 79.8 \\
\hline \multicolumn{5}{|c|}{ Environment domain } \\
\hline $0-15$ & 1 & 0.5 & 1 & 0.4 \\
\hline $16-25$ & 42 & 19.5 & 57 & 21.6 \\
\hline $26-30$ & 66 & 30.9 & 102 & 38.6 \\
\hline $31-35$ & 82 & 38.2 & 83 & 31.4 \\
\hline $36-40$ & 23 & 10.7 & 21 & 8 \\
\hline
\end{tabular}

Note: Abbreviation $\mathrm{QoL}=$ quality of life. 
In the psychological domain, $58.9 \%$ of the survivors and $68.1 \%$ of the control group demonstrated satisfaction. The difference observed between the groups, was compensated for by the $39.6 \%$ of the survivors who mentioned being very satisfied.

Within the social domain, the results were one again compatible with the maximum level of satisfaction, for the survivors $(86.4 \%)$ as well as the control group $(79.8 \%)$.

After analyzing the degree of satisfaction using the global QoL in the two groups, the frequency distribution of the most frequently occurring responses was verified. The data are organized in Table 5 .

The frequencies of the responses presented recorded similar results, that is, both groups' maintained high scores, signifying a satisfactory or very satisfactory QoL. There is a predominance of high values in the group of survivors, yet there was no difference found between the mean and the median of them.

After investigating the variables that are likely to interfere negatively on the QoL of survivors, a logistic regression had been carried out with the variables that showed relevance. Some, although did not present significant value, were analyzed by a multivariate evaluation. So, regarding males (Table 6) anxiety $(p=0.000)$, premature ejaculation $(p=0.033)$, loss of libido $(p=0.049)$, being a provider $(p=0.004)$ and advanced age $(p=$ 0.015), were the factors that were more likely to interfere negatively on the QoL.

Regarding the female survivors the risk factors taken in account in the multivariate analisys, with probability of interference of QoL are the following: anxiety $(p=0.007)$, low level of schooling $(p=0.022)$, not having a stable partner, $(p=0.019)$, being the home provider $(p=0.025)$ and at last not being a Caucasian $(p=0.048)$, is organized in Table 7.

Table 8 shows the presence of mood disorder (anxiety, $p=0.000$ and depression, $p=0.000$ ) and the work condition $(p=0.034)$, classified as manual work (farmer, housework, manicure) are risk factors for the QoL whether or not the transplantation has been carried out or not.

\section{Discussion and Conclusions}

The results of the present study show that survivors' quality of life is satisfactory, considering the satisfaction's levels presented in the WHOQOL. Despite the complications brought by transplant, such as ocular sicca syndrome, osteoporosis, early menopause, infertility, and osteonecrosis, the results are justified by the survivors' comprehension of life. After all, QoL is a subjective well-being feeling.

With the objective of verifying if the QoL of the long-term survivors differ or not from the general population, a control group is created, composed of blood donors.

The composition of the group may not have been completely adequate once taking into account that the

Table 5. Frequency, median and mean (s.d.) for each domain of QoL.

\begin{tabular}{|c|c|c|c|c|c|}
\hline Domains & Min & $\operatorname{Max}$ & Freq. & Median & Mean (s.d.) \\
\hline \multicolumn{6}{|l|}{ Physical } \\
\hline Survivor & 17 & 35 & 30 & 30 & $29.7 \pm 4.1$ \\
\hline Control & 15 & 35 & 30 & 30 & $29.5 \pm 3.9$ \\
\hline \multicolumn{6}{|l|}{ Psychological } \\
\hline Survivor & 9 & 30 & 26 & 24.5 & $24.1 \pm 3.3$ \\
\hline Control & 13 & 30 & 23 & 24 & $23.6 \pm 3.2$ \\
\hline \multicolumn{6}{|l|}{ Social } \\
\hline Survivor & 5 & 15 & 15 & 13 & $12.2 \pm 2.2$ \\
\hline Control & 5 & 15 & 12 & 12 & $12 \pm 2$ \\
\hline \multicolumn{6}{|l|}{ Environment } \\
\hline Survivor & 13 & 40 & 31 & 30 & $29.5 \pm 4.9$ \\
\hline Control & 13 & 40 & 29 & 29 & $28.9 \pm 4.8$ \\
\hline
\end{tabular}

Note: $s . d .=$ standard deviation; $\min =$ minimum; $\max =$ maximum; freq. $=$ frequency. 
Table 6. Distribution of the variables of interference in quality of life (QoL) and their odds ratios, confidence indices and values of $p$ gross and adjusted regarding male survivors, according to the model of the univariate and multivariate analysis.

\begin{tabular}{|c|c|c|c|c|c|c|}
\hline \multirow[b]{2}{*}{ Variables } & \multicolumn{2}{|c|}{$\mathrm{RC}$} & \multicolumn{2}{|c|}{ IC 95\% } & \multicolumn{2}{|c|}{$p$} \\
\hline & Gross & Adjusted & Gross & Adjusted & Gross & Adjusted \\
\hline Anxiety & 15.6 & 15.1 & $3.8-63.7$ & $3.8-60.9$ & 0.000 & 0.000 \\
\hline Depression & 8.6 & 2.0 & $2.1-33.5$ & $0.35-11.5$ & 0.425 & \\
\hline $\begin{array}{c}\text { Premature } \\
\text { ejacul. }\end{array}$ & 16.4 & 11.5 & $1.8-144.9$ & $1.2-09.7$ & 0.000 & 0.033 \\
\hline Loss of libido & 3.8 & 2.7 & $1.6-8.9$ & $1.0-7.2$ & 0.001 & 0.049 \\
\hline Loss of fertility & 4.2 & 3.4 & $1.3-12.9$ & $0.87-13.8$ & 0.078 & \\
\hline Provider & 2.3 & 5.7 & $1.1-4.9$ & $1.7-8.7$ & 0.019 & 0.004 \\
\hline GVHD-a & 0.3 & 0.28 & $0.11-1.0$ & $0.07-1.1$ & 0.074 & \\
\hline $\begin{array}{c}\text { Level of } \\
\text { schooling }\end{array}$ & 2.0 & 1.4 & $1.0-4.2$ & $0.58-3.6$ & 0.409 & \\
\hline Work condition & 2.4 & 1.9 & $0.9-6.6$ & $0.49-7.5$ & 0.343 & \\
\hline Current age & 1.4 & 2.4 & $0.9-2.2$ & $1.2-4.7$ & 0.090 & 0.015 \\
\hline Intelect/Manual & 1.7 & 0.68 & $0.8-3.4$ & $0.23-1.9$ & 0.481 & \\
\hline Time after BMT & 1.8 & 1.5 & $0.7-4.2$ & $0.44-5.4$ & 0.464 & \\
\hline GVHD-c & 0.5 & 0.35 & $0.1-1.4$ & $0.07-1.6$ & 0.181 & \\
\hline Religion & 1.7 & 1.1 & $0.7-3.9$ & $0.35-3.5$ & 0.848 & \\
\hline
\end{tabular}

Note: $\mathrm{RC}=$ Odds Ratios; $\mathrm{IC}=$ Confidence Index; $p=$ Probability.

Table 7. Representative distribution of the variables of interference in the QoL and their odds ratios, confidence indices and valuesof $p$ gross and adjusted regarding women survivors according to the model of the univariate and multivariate analysis.

\begin{tabular}{|c|c|c|c|c|c|c|}
\hline \multirow[b]{2}{*}{ Variables } & \multicolumn{2}{|c|}{$\mathrm{RC}$} & \multicolumn{2}{|c|}{ IC $95 \%$} & \multicolumn{2}{|c|}{$p$} \\
\hline & Gross & Adjusted & Gross & Adjusted & Gross & Adjusted \\
\hline Anxiety & 3.8 & 6.6 & $1.2-11.3$ & $1.7-25.5$ & 0.011 & 0.007 \\
\hline Depression & 5.0 & 1.9 & $0.9-26.8$ & $0.19-19.7$ & 0.564 & \\
\hline Schooling & 2.8 & 4.5 & $1.0-8.1$ & $1.2-16.4$ & 0.040 & 0.022 \\
\hline Unstable partner & 2.7 & 4.7 & $0.98-7.6$ & $1.3-16.9$ & 0.044 & 0.019 \\
\hline Provider & 2.6 & 4.0 & $1.0-7.0$ & $1.2-13.6$ & 0.045 & 0.025 \\
\hline Dyspareunia & 2.4 & 3.2 & $0.8-6.8$ & $0.80-12.7$ & 0.098 & \\
\hline Economic level & 2.4 & 1.3 & $0.9-6.5$ & $0.36-5.0$ & 0.637 & \\
\hline Diag & 0.4 & 0.69 & $0.2-1.1$ & $0.19-2.4$ & 0.567 & \\
\hline Ethnicity & 3.2 & 6.4 & $0.7-13.7$ & $1.0-40.5$ & 0.095 & 0.048 \\
\hline Current age & 0.6 & 0.95 & $0.4-1.1$ & $0.35-2.5$ & 0.934 & \\
\hline Marital status & 2.0 & 1.4 & $0.8-5.2$ & $0.12-17.9$ & 0.755 & \\
\hline GVHD-a & 0.5 & 0.53 & $0.1-1.5$ & $0.12-2.3$ & 0.408 & \\
\hline
\end{tabular}

Note: $\mathrm{RC}=$ Odds Ratio; $\mathrm{IC}=$ Confidence Index; $p=$ Probability 
Table 8. The distribution of the variables of interference in QoL and their odds ratios, confidence index and values of $p$ crude and adjusted regarding the group of survivors and the control group according to univariable and multivariable analysis.

\begin{tabular}{ccccccc}
\hline & \multicolumn{2}{c}{ RC } & \multicolumn{2}{c}{ IC 95\% } & \multicolumn{1}{c}{$p$} \\
\hline Variables & Gross & Adjusted & Gross & Adjusted & Gross & Adjusted \\
\hline Depression & 8.6 & 4.6 & $4.4-16.8$ & $2.3-9.0$ & 0.000 & 0.000 \\
Anxiety & 7.3 & 4.6 & $4.0-13.2$ & $2.5-8.3$ & 0.000 & 0.000 \\
Intelec/Manual & 1.8 & 1.5 & $1.2-2.6$ & $1.0-2.3$ & 0.001 & 0.034 \\
Cond/Work & 1.8 & 1.3 & $1.0-3.0$ & $0.76-2.4$ & 0.289 & 0.383 \\
Religion & 1.3 & 1.2 & $0.9-1.9$ & $0.78-1.8$ & 0.294 & 0.660 \\
Ethnicity & 1.4 & 1.3 & $0.8-2.3$ & $0.77-2.3$ & $0.72-1.6$ & 0.117 \\
Economic level & 1.3 & 1.0 & $0.9-1.9$ & $0.4-0.8$ & $0.48-1.0$ & 0.445 \\
Gender & 0.5 & 0.72 & $1.1-2.7$ & $0.73-2.0$ & \\
Schooling & 1.7 & 1.2 & & &
\end{tabular}

Note: $\mathrm{RC}=$ Odds Raitio; $\mathrm{IC}=$ Confidence Index $; p=$ Probability.

necessary restrictions for acceptance as a blood donor surpass the average population's health. However, it was believed that if a parameter of criteria correlation was established, this parameter would be conducive to a valorization of the results that indicated acquisitions obtained for the survivors in the comparative analysis of the study. This, in fact, did occur.

The results show that there is no significant difference between the two groups in terms of the QoL. This is also the case with all the risks that the BMT entails. This similarity raises a question: Is it possible for a survivor to be satisfied in spite of everything they have lived through, and the consequences?

To reflect on this question, you must go beyond statistical data. The insertion of added subjective indicators into the objectives is fundamental [11]. The use of the questionnaire and the WHOQOL makes it possible to obtain subjective information of objective reality, through the perception of the patient in relation to their personal lived experiences.

Subjectivity is a questionable and polemical construct in clinical care, as well as a consequence of the innumerable possibilities of subjective interpretations. Therefore, a view of contextual questions of subjectivity is fundamental.

When Helder, D.I. et al [12] say that QoL is a subjective well-being, it means that each individual assigns a greater or lesser value to his/her life experience, according to his/her perceived multifactorial composition [13] [14].

The position that the survivor presents when faced with events, is a manifestation of a compilation of thoughts and affections. Value is assigned according to the sensitivity with which an experience is lived, and not only through the idea that is born out of a process of reasoning [15].

Through the responses and reflections of the survivors, it is verified in the present study that there is a behavioral element that indicates a tendency to overcome one's circumstances, through the use of internal resources. They take advantage of external events to recreate something that can be transformed, making possible an adaptation to one's circumstances that will otherwise be characterized as unchangeable. That is, there is evidence of resilience.

Min, J.A. et al [16] mention that resilience is expressed when there is a presence of risk factors, and that resilience will not exist where there are no risks. These authors view risk as a factor that is directly linked to the result that is provoked. That is, the same variable may present different results depending on the subject and the life experiences of each one [17].

Windle, G. et al [18] agree with these authors, stating that resilience facilitates a personal recycling of the individual through renewed energy, reorganization of strategies for confronting problems, and adjustment with the use of creative forms for managing adversity in real life. Following this line of thought, it is necessary that one 
suffer loss, to then be able to emerge from the darkness [19].

When faced with real threats, the survivors present attitudes of resilience, and with this, they reach a transformation of the emotional engrams, whose consolidation takes shape in the strengthening of themselves, and in the discovery of a sense of existence and their own life.

Living a near-death experience and overcoming it, the survivors seek a greater purpose for their existence. The survivors believe that they are alive, while many die, so there must be a special reason for this [20].

The following testimony from a survivor who has a son post-transplanted exemplifies this I am living extra hours, I could be dead. I thought I would not live much longer, and now I know I will have someone surviving me. I gave life. What more could I want?!

Apparently, the annoying effects of the remaining symptoms lose their intensity over time. There is a relativity of values that informs this tolerant attitude. This transformation takes place without denying reality; they simply find a certain approach for every experience. The election of a position when confronted with loss and gains is based on what makes real sense.

The time that passes under the effects of adversity and redemption that go along with the ups and downs, creates a kind of learners' laboratory in the evolution of life. This allows for the maturation of a new way of being, where the transplant forms part of the difficulties of life, and is not one's life itself. This is the main qualitative difference.

In the analysis of the responses of the survivors, it is observed that over time, there is an adjustment in the perception of normality for a greater adaptation of expectations and a shift in consciousness. This confirms the importance of referential transformation that is carried out over the years. This event also may be explained by the temporary relativization of values, which allows for a new construction of a new perspective and view.

The experience of the transplant and the future imposes a temporary reality that results in a splitting of the present time. Memories drive towards the base and origin of each one. With hope, it is possible to envision a new being. Remembering that the past is a way to reduce or re-route the past and the future, so that once an experience is recognized and over, it may be delivered to the present, which is open to the future [21] [22].

Participating in and assuming the choices and risks that come with life, as well as fleeing from experiences may prevent errors but it also prevents living. Knowledge received only through reasoning is not the same as knowing that you may learn from the dialectic of thinking, feeling, and living. That is why survivors consider themselves as having a very good global QoL, even living with consequences. The self-reported QoL is not static; it may vary due to the complex integration of multifactorial variables. Perspective and the maturity that result from life experience promote the functional capacity to overcome circumstances.

The global results demonstrate the importance of affective comprehension, psychological malleability, and of understanding that which life reveals. It is possible to go much further that what one thinks, even when it seems as though one cannot go on, or even doubting one's own survival. This interpretation explains the apparent discrepancy between real facts, responses, and attitudes assumed by survivors when they comment on their own QoL condition. Not succumbing to adversity allows for a sense of tolerance, gratitude, and a greater taking advantage of the opportunities that life has to offer.

The way the survivors have responded shows the inclusion and juxtaposition of positive and negative aspects. In spite of difficulties, they appreciate what is good. The results of the difficulties, limits, and health problems, were compensated for by the synthesis of positive appearances.

To conclude this discussion, we can respond to the central question that guides this study. After confronting and defeating the illness process, and assimilating the consequences of the transplant, the satisfaction of the survivors with QoL is based on the following protection factors: the passing of time, perception, psychosocial transition, and resilience.

The results show that there is no significant difference between the two groups in terms of the QoL but the perception of QoL of long-term survivors differing from the general population. This study shows that the transplant allows for longevity and also well-being, by becoming part of the person, living in the best way possibly. They find meaning for their own existence. The composition and management of existence are determining factors for living a good life, with satisfactory quality.

The struggle of being for so long fighting against many adversities, diseases, treatments, transplants, gives the survivors a new self-concept, where they find themselves truly winners. They acquire a positive change in the perception of live, appreciate every aspect of their time with other people, and enjoy their retreat with a spiritual growth, achieving, in other words, a psychological equilibrium. 
Therefore, the combination of the present study's quantitative and qualitative results shows that the survivors' quality of life is satisfactory, reaching, not only the standards of healthy controls, but overwhelming their capability of dealing with problems through an optimistic analysis of the situation. And, so, here lies the importance of integrating subjective and objective aspects in the evaluation of QoL.

Finally, people that undergo and survive the transplant are recognized for the journey they have taken, and for having arrived where they have arrived. They have survived pain and imminent death, but receive satisfaction with the discovery of a new view from this experience.

\section{Acknowledgements}

We thanked Hospital de Clínicas which allowed this research, and specially Eurípedes Ferreira, Marco Antonio Bitencourt, Maria Joana Mader-Joaquim, Tânia Maria Baibich, Eliane Cesário, Paulo Tadeu Almeida, Ielza Maria Kafka, Renato Nickel, Euza Tieme Toyonaga Ortega, Regina Consuelo Sperandio and Heliz Regina Neves for reviewing this study, as well as all BMT survivors who collaborated with this study.

\section{Conflict of Interests}

The authors declare no conflict of interests.

\section{References}

[1] WHOQOL Group (1998) The World Health Organization Quality of Life Assessment (WHOQOL): Development and General Psychometric Properties. Social Science \& Medicine, 46, 1569-1585. http://dx.doi.org/10.1016/S0277-9536(98)00009-4

[2] Aspinwall, L.G. and Tedeschi, R.G. (2010) The Value of Positive Psychology for Health Psychology: Progress and Pitfalls in Examining the Relation of Positive Phenomena to Health. Annals of Behavioral Medicine, 39, 4-15. http://dx.doi.org/10.1007/s12160-009-9153-0

[3] Mosher, C.E., Duhamel, K.N., Rini, C., Corner, G., Lam, J. and Redd, W.H. (2011) Quality of Life Concerns and Depression among Hematopoietic Stem Cell Transplant Survivors. Support Care Cancer, 19, 1357-1365.

[4] Chida, Y. and Steptoe, A. (2008) Positive Psychological Well-Being and Mortality: A Quantitative Review of Prospective Observational Studies. Psychosomatic Medicine, 70, 741-756. http://dx.doi.org/10.1097/PSY.0b013e31818105ba

[5] Neitzert, C.S., Ritvo, P., Dancy, J., Weiser, K., Murray, C. and Avery J. (1998) The Psychosocial Impact of Bone Marrow Transplantation: A Review of the Literature. Bone Marrow Transplant, 22, 409-422. http://dx.doi.org/10.1038/sj.bmt.1701358

[6] Andrykowsk, M.A., Brandy, M.J. and Henslee-Downey, P.J. (1994) Psychosocial Factors Predictive of Survival after Allogeneic Bone Marrow Transplantation for Leukemia. Psychosomatic Medicine, 56, 432-439. http://dx.doi.org/10.1097/00006842-199409000-00008

[7] De Mello, C.N.H., Martins, M.L.C., Chiattone, D., Pinto, K.O., de Oliveira Santos, N. and de Luciant, M.C.S. (2007) Intervenções psicológicas realizadas na clínica onco-hematolótica: Discussão acerca das possibilidades clínicas apresentadas na literatura. Psicologia Hospitalar, 5, 73-99.

[8] Hoodin, F. and Weber, S. (2003) A Systematic Review of Psychosocial Factors Affecting Survival after Bone Marrow Transplantation. Psychosomatics, 44, 181-195. http://dx.doi.org/10.1176/appi.psy.44.3.181

[9] Fleck, M.P.A., et al. (2000) Application of the Portuguese Version of the Abbreviated Instrument of Quality Life WHOQOL-Bref. Revista de Saúde Pública, 34, 178-183. http://dx.doi.org/10.1590/S0034-89102000000200012

[10] Yates, J.W., Chalmer, B. and Mckegney, F.P. (1980) Evaluation of Patients with Advanced Cancer Using the Karnofsky Performance Status. Cancer, 45, 2220-2224. http://dx.doi.org/10.1002/1097-0142(19800415)45:8<2220::AID-CNCR2820450835>3.0.CO;2-Q

[11] Salsman, J.M., Lai, J.S., Hendrie, H.C., Butt, Z., Zill, N., Pilkonis, P.A., Peterson, C., Stoney, C.M., Brouwers, P. and Cella, D. (2014) Assessing Psychological Well-Being: Self-Report Instruments for the NIH Toolbox. Quality of Life Research, 23, 205-215.

[12] Helder, D.I., Bakker, B., Heer, P., Veen, F., Vossen, J.M.J.J., Wit, J.M. and Kaptein, A.A. (2004) Quality of Life in Adults Following Bone Marrow Transplantation during Childhood. Bone Marrow Transplantation, 33, 329-336. http://dx.doi.org/10.1038/sj.bmt.1704345

[13] Meneses, K. and Benz, R. (2010) Quality of Life in Cancer Survivorship: 20 Years Later. Seminars in Oncology Nursing, 26, 36-46. http://dx.doi.org/10.1016/j.soncn.2009.11.006 
[14] Lucas, R.E. and Donnellan, M.B. (2007) How Stable Is Happiness? Using the Starts Model to Estimate the Stability of Life Satisfaction. Journal of Research in Personality, 41, 1091-1098. http://dx.doi.org/10.1016/j.jrp.2006.11.005

[15] Wingard, J.R., Huang, C., Sobocinski, K.A., Andrykowski, M.A., Cella, D., Rizzo, J.D., Brady, M., Horowitz, M.M. and Bishop, M.M. (2010) Factors Associated with Self-Reported Physical and Mental Health after Hematopoietic Cell Transplantation. Biology of Blood and Marrow Transplantation, 16, 1682-1692.

[16] Min, J.A., Lee, N.B., Lee, C.U., Lee, C. and Chae, J.H. (2012) Low Trait Anxiety, High Resilience and Their Interaction as Possible Predictors for Treatment Response in Patients with Depression. Journal of Affective Disorders, 137, 61-69. http://dx.doi.org/10.1016/j.jad.2011.12.026

[17] Marum, G., Clench-Aas, J., Nes, R.B. and Raanaas, R.K. (2014) The Relationship between Negative Life Events, Psychological Distress and Life Satisfaction: A Population-Based Study. Quality of Life Research, 23, 601-611.

[18] Windle, G., Bennett, K.M. and Noyes, J. (2011) A Methodological Review of Resilience Measurement Scales. Health and Quality of Life Outcomes, 9, 8. http://dx.doi.org/10.1186/1477-7525-9-8

[19] Min, J.A., Jung, Y.E., Kim, D.J., Yim, H.W., Kim, J.J., Kim, T.S., Lee, C.U., Lee, C. and Chae, J.H. (2013) Characteristics Associated with Low Resilience in Patients with Depression and/or Anxiety Disorders. Quality of Life Research, 22, 231-241. http://dx.doi.org/10.1007/s11136-012-0153-3

[20] van Nooten, F.E., Koolman, X. and Busschbach, J.J.V. (2014) Thirty Down, Only Ten to Go?! Awareness and Influence of a 10-Year Time Frame in TTO. Quality of Life Research, 23, 377-384.

[21] Lecic-Tosevski, D., Vukovic, O. and Stepanovic, J. (2011) Stress and Personality. Psychiatriki, 22, $290-297$.

[22] Parkes, C.M. (2006) Love and Loss: The Roots of Grief and Its Complications. Routledge, London.

\section{Abbreviations}

BMT: Bone Marrow Transplant

BMTS-HC-UFPR: Bone Marrow Transplant Service of the Hospital of the Clinics of the Federal University of Paraná.

GVHD: Graft-versus-Host Disease

KPSS: Karnofsky Performance Status Scale

QoL: Quality of Life

WHOQOL: World Health Organization Quality of Life 
Scientific Research Publishing (SCIRP) is one of the largest Open Access journal publishers. It is currently publishing more than 200 open access, online, peer-reviewed journals covering a wide range of academic disciplines. SCIRP serves the worldwide academic communities and contributes to the progress and application of science with its publication.

Other selected journals from SCIRP are listed as below. Submit your manuscript to us via either submit@scirp.org or Online Submission Portal.
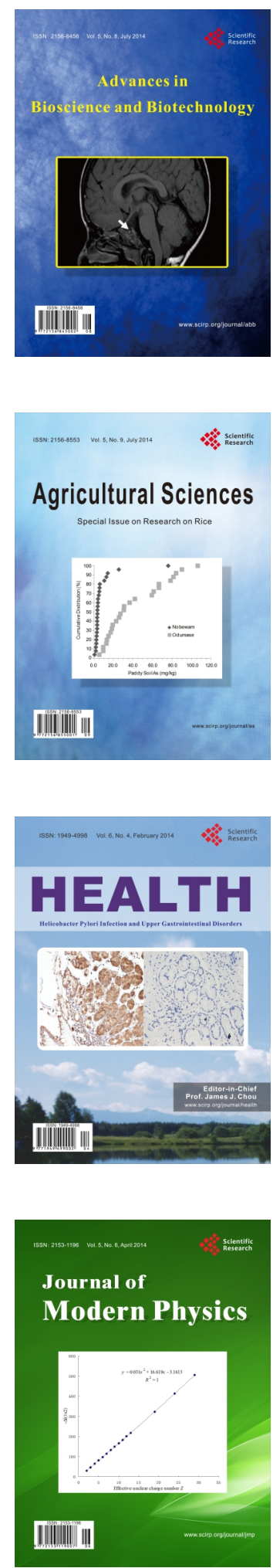
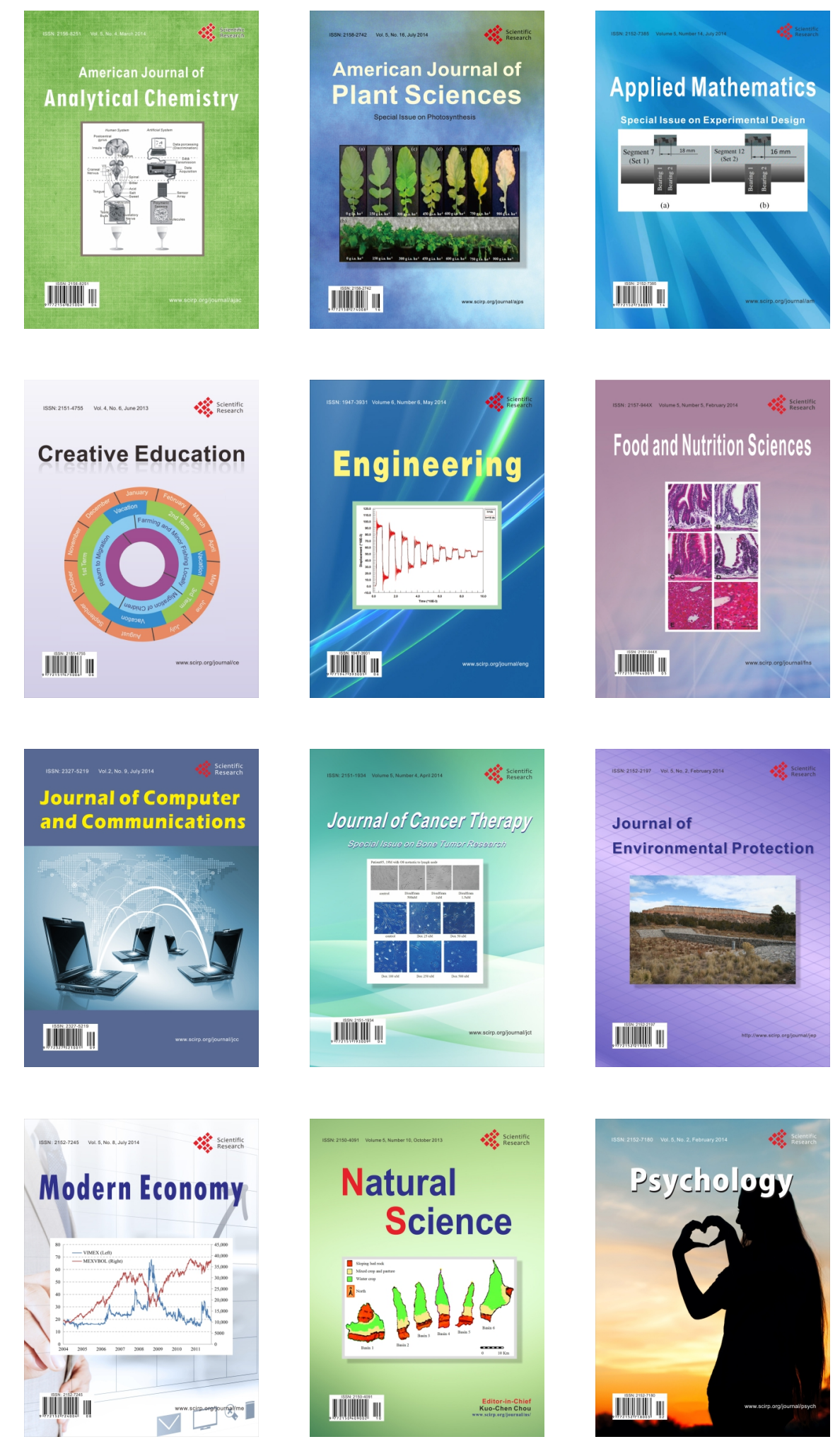